\title{
Adaptability Study of Improved Sesame (Sesamumindicum L.) Varieties at Harari Region
}

\author{
*Habte Berhanu Adugna Hunduma Motuma Dalasa Hailu Mekuria \\ Fadis Agricultural Research Center, P. O. Box 904, Harar, Ethiopia
}

\begin{abstract}
Sesame (Sesamum indicum L.) is an important oilseed crop in the tropics and subtropics. Field trials were conducted during the main rainy seasons of 2017, and 2019 at Harari regional state of Kile kebele with the objective to study the adaptability of released sesame varieties. Twelve improved varieties of sesame including standard check (Obsa) were used as planting materials. The experiment was laid out in Completely Randomized Block Design (RCBD) with three replications. Analysis of variance showed that significant variation was observed among the varieties for days to flowering, days to maturity, number of branches per plant, number of pods per plant, plant height and grain yield. Accordingly, Chalasa, Srinka-2 Srinka-1and Hirhir varieties found to be best performing varieties among the test varieties and hence were recommended for further demonstration and scaling up in the study area and similar agro-ecologies.
\end{abstract}

Keywords: Varieties, adaptability, and environment

DOI: $10.7176 /$ ALST/85-01

Publication date: January $31^{\text {st }} 2021$

\section{Introduction}

Ethiopian sesame is among the highest quality in the world, as seeds are naturally produced at near-organic levels (Fantaye et al., 2018). Sesame seed is branded as Humera, Gonder and Wollega types which are well known in the world market by their white color, sweet taste, and aroma. The Humera and Gondar sesame seeds are suitable for bakery and confectionary purposes; on the other hand, the high oil content of the Wollega sesame seed gives a major advantage for edible oil production (Yamanura, 2008). The current sesame production in Ethiopia has many opportunities, such as high market demand, a large area with suitable environments for production (Northwestern and South-Western Ethiopia), growing in low moisture areas, presence of genetic diversity to improve production yield potential and export demanded very competitively worldwide (Wijnands et al., 2007).

Survey of production constraints made by AGP-II project in the Harari region indicated that sesame producing farmers in the area are not accessible to new and improved sesame varieties and they rather they produce varieties that were released 7-10 years ago which are now these varieties are becoming susceptible and low yielder due to sesame diseases and other production constraints. During the survey mission in the group discussion, the participant framers pointed out that lack of awareness on the importance and utilization of sesame is common in the community. There is also the problem of late distribution of the seed for the farmers and also the seed distributed is poor both quality and quantity. Farmers of the districts noted that the shortages of improved varieties are the major problem. Generally, the number of improved sesame varieties released and introduced in the study area is quite a few and old and hence, introducing different recently released sesame varieties which are resistant and high yielder are needed to improve farmers' access to different varieties in the area. Hence, introducing high yielder and disease-resistant varieties for the sesame producing community of the area is quite an important aspect to improve the production and productivity of this crop in this production area. Therefore, this experiment was conducted with the objective to evaluate different introduced sesame varieties for their adaptability in the study area for further scaling up activities.

\section{MATERIALS AND METHODS}

\section{Experimental Site}

The study was conducted at Harari Regional state, Sofi district, Kile kebele, where this kebeles is known for its frequent low moisture stress. Kile kebele is situated at a distance of about $20 \mathrm{~km}$ away from Harar city in the eastern direction. The experiment was conducted during the 2017 and 2019 main cropping season.

\section{Experimental Materials}

The experimental materials were comprised of twelve released sesame varieties including one standard check (Obsa). Nine released sesame varieties viz. Srinka-1, Srinka-2, Setit-1, Setit-2, Humera-1, Gonder, Baha-Necho, Baha-Zeyit, and Hirhir,) were introduced from Humara Agricultural Research Center (HaRC) and two released varieties viz. Adi and Chalasa were introduced from Bako Agricultural Research Center (BARC).

\section{Experimental Design}

The trial was laid out in Randomized Complete Block Design (RCBD) in three replications. Each Variety was 
planted in 6 rows of $40 \mathrm{~cm}$ spacing between rows and $10 \mathrm{~cm}$ between plants with row length of $3 \mathrm{~m}$.

\section{Data Analysis}

\section{Analysis of Variance (ANOVA)}

To estimate the variation among varieties the data recorded was analyzed using ANOVA (Steel et al., 1997). Duncan Multiple Range Test (DMRT) was used to compare the means of different treatments. Analysis of variance (ANOVA) was conducted using the Statistical Analysis System (SAS) computer software program

\section{RESULTS AND DISCUSSIONS}

Results of analysis of variance showed that there is significant variation among the test varieties for all considered parameters such as days to flowering, days to maturity, number of branches per plant, plant height, number of pods per plant, number of seeds per pod and Grain yield per hectare $(\mathrm{kg} / \mathrm{ha})$. Tadese M. and Misgana M. reported that significant variations were observed on days to flowering and days to maturity at $(\mathrm{P}<0.01)$ among tested Sesame varieties. Similarly, Fantaye B et al., 2018 reported that combined analysis of variance results showed that sesame genotypes evaluated in the study were significantly $(p<0.01)$ influenced by the environment, genotype and genotype by environment interaction (GEI).

Significant differences were observed among tested varieties for the trait such as Days to flowering, Days to maturity, Number of branching per plant, Plant height, Number of pods per plant, Number of seeds per pod and grain yield. Gonder-1 variety was early flowering as compared to about five varieties but when it is compared with check variety Obsa, it is not significantly earlier (Table 1) Regarding to the days to maturity, variety Srinka-1 is significantly early maturing than the check variety Obsa however, statistically is not early maturing as compared to the remaining test varieties. The maximum number of branches was observed from variety Srinka-1 and followed by Gonder-1 even though both varieties are not statistically significantly different. The lowest number of branches was observed from variety of Adi. Highly significant variation was observed among the varieties for number of pods per plant. The maximum number of pods per plant was recorded from Srinka-1 and followed by Baha-Necho, Gonder-1 and Chalasa. Significant variation was also observed among the test varieties for number of seeds per pod. Accordingly, Humera-1, Setit-2, Srinka-1, Gonder, Setit-1, Baha-Necho and Chalasa gave a higher number of seeds per pods than the standard check (Obsa). Maximum grain yield was harvested from Chalasa variety $(787.6 \mathrm{~kg} / \mathrm{ha})$ followed by Baha-Necho, Srinka-2, Srinka-1 and Hirhir; Similarly, Chalasa, Srilinka-1, Baha-Necho and Gonder-1 showed the maximum number of pods per plant than the standard check, indicating that number of pods per plant has a contribution for grain yield increment.

Table.1. The combined mean of grain yield and other parameters of sesame varieties tested over years (2017 and 2019)

\begin{tabular}{lllllll}
\hline Treatment & FD & MD & NB & PPP & PH & Grain y(kg/ha \\
\hline Adi & $53 \mathrm{bc}$ & $99 \mathrm{ab}$ & $4.35 \mathrm{bc}$ & $72.07 \mathrm{ab}$ & $65.4 \mathrm{~d}$ & $611.1 \mathrm{abc}$ \\
Gonder-1 & $48 \mathrm{c}$ & $96 \mathrm{~b}$ & $4.95 \mathrm{bc}$ & $58.17 \mathrm{~b}$ & $91.67 \mathrm{a}$ & $568.9 \mathrm{abc}$ \\
Baha-Necho & $51 \mathrm{bc}$ & $112 \mathrm{a}$ & $3.783 \mathrm{c}$ & $68.88 \mathrm{ab}$ & $77.02 \mathrm{c}$ & $762.4 \mathrm{a}$ \\
Baha-Zeyit & $53.33 \mathrm{abc}$ & $118 \mathrm{a}$ & $4.283 \mathrm{bc}$ & $55.35 \mathrm{~b}$ & $83.4 \mathrm{bc}$ & $609.5 \mathrm{abc}$ \\
Hirhir & $54.67 \mathrm{abc}$ & $96 \mathrm{~b}$ & $5.45 \mathrm{abc}$ & $82.05 \mathrm{ab}$ & $94.17 \mathrm{a}$ & $708.8 \mathrm{ab}$ \\
Humera-1 & $57.33 \mathrm{ab}$ & $97 \mathrm{ab}$ & $5.05 \mathrm{abc}$ & $58.85 \mathrm{~b}$ & $84.95 \mathrm{bc}$ & $389.5 \mathrm{c}$ \\
Srinka-1 & $54.33 \mathrm{abc}$ & $96 \mathrm{~b}$ & $6.6 \mathrm{a}$ & $107.43 \mathrm{a}$ & $90.1 \mathrm{a}$ & $714.4 \mathrm{ab}$ \\
Srinka-2 & $59.83 \mathrm{a}$ & $102 \mathrm{a}$ & $5.15 \mathrm{abc}$ & $67.63 \mathrm{ab}$ & $90.6 \mathrm{a}$ & $718.8 \mathrm{ab}$ \\
Setit-1 & $55.5 \mathrm{abc}$ & $99 \mathrm{ab}$ & $4.933 \mathrm{bc}$ & $69.93 \mathrm{ab}$ & $87.38 \mathrm{ab}$ & $612.9 \mathrm{abc}$ \\
Setit-2 & $57.5 \mathrm{ab}$ & $86 \mathrm{ab}$ & $5 \mathrm{abc}$ & $59.95 \mathrm{~b}$ & $88 \mathrm{ab}$ & $487.9 \mathrm{bc}$ \\
Obsa & $50.67 \mathrm{bc}$ & $96 \mathrm{~b}$ & $4.833 \mathrm{bc}$ & $65.43 \mathrm{ab}$ & $89.77 \mathrm{ab}$ & $581.5 \mathrm{bc}$ \\
Calasa & $54.67 \mathrm{abc}$ & $98 \mathrm{ab}$ & $5.617 \mathrm{ab}$ & $85.62 \mathrm{ab}$ & $84.77 \mathrm{bc}$ & $787.6 \mathrm{a}$ \\
\hline CV $(\%)$ & 9.8 & 3.8 & 24.6 & 26 & 10.4 & 26.1 \\
LSD & 6.115 & 4.341 & 1.420 & 37.67 & 10.42 & 262.4 \\
\hline
\end{tabular}

Key: $\mathrm{FD}=$ days to flowering, $\mathrm{DM}=$ days to maturity, $\mathrm{NB}=$ number of branches, $\mathrm{PH}=$ plant height, $\mathrm{PPP}=$ pods per plant, $\mathrm{GY}=$ grain yield, $\mathrm{CV}=$ coefficient of variation and $\mathrm{LSD}=$ least significant differences

\section{CONCLUSION AND RECOMMENDATION}

Analysis of variance showed that it is statistically significant differences among the treatments for all the traits considered in this study. This showed that there is a great opportunity for sesame improvement by breeding for these traits. In terms of grain yield and yield traits, varieties such as Chalasa, Srinka-2, Srinka-1 and Hirhir showed higher performance than the standard check. Accordingly, these varieties, Chalasa, Srinka-2 Srinka-1and Hirhir were recommended for further demonstration and scaling up in the study area and similar agro-ecologies. 


\section{REFERENCES}

Central Statistical Agency 2008. Agricultural sample survey 2007/08 (2000 E.C.), Vol. 1. Report on area and production of major crops for private peasant holdings, Meher season. Statistical Bulletin 417, Addis Ababa, Ethiopia.

Central Statistical Agency 2013. Agricultural Sample Survey 2012/2013 (2005 E.C.), Report on Area and Production of Crops (Private Peasant Holdings, Meher Season), Vol. 1. Statistical Bulletin, Addis Ababa.

Fantaye Belay, Hintsa Meresa and Atsbha Gebreslasie 2018. Evaluation of the performance of some white seeded sesame (Sesamum Indicum L.) genotypes using GGE bi-plot analysis in Northern Ethiopia. Vol. 9(1), pp. 19

Gulhan, E., Melih, T., Kenan, T., 2004. Analysis of genetic diversity in Turkish sesame (Sesamum indicum L.) populations using RAPD markers. Genetic Resources and Crop Evolution 51: 599-607.

Nath,R, Chakraborty, A. Chakraborty, 2000. Effect of Microclimatic Parameters at Different Sowing Dates on Capsule Production of Sesame (Sesamum indicum L.). In: A Tropical Humid Region. Journal of Agronomy and Crop Science 184: 247-252.

Participatory Agricultural Production Constraint Analysis in Oromia, (PRA Survey, 2016)

Tadese Mesera and Misgana Mitiku "Performance Evaluation of Sesame (Sesamum indicum L.) Varieties in Lowland Area of South Omo Zone, SNNPR, Ethiopia", International Journal of Research in Agriculture and Forestry, vol. 4, no. 9, pp. 38-41, 2017.

Wijnands J, Biersteker J, Hiel R 2007. Oilseeds Business Opportunities in Ethiopia. Survey report, Ministry of Agriculture, Nature and Food Quality, The Netherlands, The Hague. pp. 8-20.

Yamanura D. 2008. Sesame Growing: An Idealized Overview. In. Oil Crops: proceedings of a workshop, Cairo, Egypt, September Riley, K.W., ed., IDRC-MR93e., IDRC-Ottawa 